\title{
The Effect of Using Peanut Meal Instead of Soybean Meal on Growth, Biochemical Composition and Fillet Color of Rainbow Trout (Oncorhynchus mykiss Walbaum, 1792)
}

\author{
Seval DERNEKBAŞI Dilara KAYA ÖZTÜRK* İsmihan KARAYÜCEL \\ Sinop University, Faculty of Fisheries, Department of Aquaculture, Sinop, Turkey
}

How to cite: Dernekbaşı, S., Kaya Öztürk, D. \& Karayücel, İ. (2020). The Effect of Using Peanut Meal Instead of Soybean Meal on Growth, Biochemical Composition and Fillet Color of Rainbow Trout (Oncorhynchus mykiss Walbaum, 1792). J. Anatolian Env. and Anim. Sciences, 6(1), $135-141$.

Atıf yapmak için: Dernekbaşı, S., Kaya Öztürk, D. \& Karayücel, İ. (2020). Soya Küspesi Yerine Yer Fıstığı Küspesinin Kullanımının Gökkuşağı Alabalığında (Oncorhynchus mykiss Walbaum, 1792) Büyüme, Biyokimyasal Kompozisyon ve Fleto Rengine Etkisi. Anadolu Çev. ve Hay. Dergisi, 6(1), $135-141$.

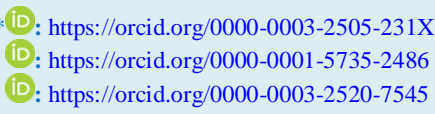

*Corresponding author's: Dilara KAYA ÖZTÜRK

Sinop University, Faculty of Fisheries,

Department of Aquaculture, Sinop, Turkey

凶: dilara.kaya55@gmail.com
Abstract: The aim of this study was to determine the effect of using peanut meal instead of soybean meal in rainbow trout (Oncorhynchus mykiss Walbaum, 1792) feeds on growth performance, biochemical composition and fillet color. For this purpose, rainbow trout $(108.70 \pm 0.09 \mathrm{~g})$ were fed for eight weeks with four different diets adjusted as iso-nitrogenic (45\% protein), iso-lipidic (19\% lipid) and iso-energetic $\left(22 \mathrm{~kJ} \mathrm{~g}^{-1}\right)$. While the CF (commercial feed) group was fed with commercial feed, three experimental diets containing 0\% (Control-C), $50 \%$ $\left(\mathrm{PNM}_{50}\right)$ and $100 \%\left(\mathrm{PNM}_{100}\right)$ peanut meal were formulated for the other groups. As a result of the 8 weeks study, the best final weight, weight gain and specific growth rate were found $\mathrm{PNM}_{50}$ group and the difference among groups was found significant. $(\mathrm{p}<0.05)$. The use of peanut meal instead of soybean meal in rainbow trout diets decreased fish meat protein ratios compared to $\mathrm{CF}$ and $\mathrm{C}$ groups. The qualities of redness, yellowness and hue were distinct between the diets in the dorsal and caudal locations. At all the measured regions in the $\mathrm{C}$ and $\mathrm{CF}$ groups did not result in any significant difference for chroma. It is thought that the differences between the measured regions in $\mathrm{L}^{*}, \mathrm{a}^{*}, \mathrm{~b} *$ are due to the fillet thickness and the preservation of the fillet coloring matter. Consequently, $50 \%$ peanut meal instead of soybean meal in trout diets could be used in diets of rainbow trout without any negative effects on growth.

Keywords: Biochemical composition, fillet color, Oncorhynchus mykiss, peanut meal, plant protein.

\section{Soya Küspesi Yerine Yer Fıstığı Küspesinin Kullanımının Gökkuşağı Alabalığında (Oncorhynchus mykiss Walbaum, 1792) Büyüme, Biyokimyasal Kompozisyon ve Fleto Rengine Etkisi}

\section{*Sorumlu yazar:}

Dilara KAYA ÖZTÜRK

Sinop Üniversitesi, Su Ürünleri Fakültesi

Su Ürünleri Yetiştiriciliği Bölümü,

Sinop, Türkiye.

凶: dilara.kaya55@gmail.com
Öz: Bu çalışmada, gökkuşağı alabalığı (Oncorhynchus mykiss Walbaum, 1792) yemlerinde soya küspesi yerine yer fistığı küspesi kullanımının balıkların büyüme performansı, biyokimyasal kompozisyon ve fileto rengine etkisininin belirlenmesi amaçlanmıştır. $\mathrm{Bu}$ amaçla izo-nitrojenik (\%45 protein), izo-lipidik (\%19 lipid) ve izo-enerjik (22 $\left.\mathrm{kJ} \mathrm{g}^{-1}\right)$ olarak hazırlanan dört farklı diyetle gökkuşağı alabalıkları $(108.70 \pm 0.09 \mathrm{~g})$ sekiz hafta süreyle beslenmiştir. CF (ticari yem) grubu ticari yemle beslenirken, diğer gruplar için \%0 (Kontrol-C), \%50 (PNM50) ve \%100 (PNM 100$)$ oranlarında yer fistığı küspesi içeren üç farklı yem hazırlanmıştır. 8 haftalık çalışma sonucunda en iyi ağırlık artışı, ağırlık kazancı ve spesifik büyüme oranı $\mathrm{PNM}_{50}$ grubundan elde edilmiş ve gruplar arası fark anlamlı bulunmuştur $(\mathrm{p}<0.05)$. Gökkuşağı alabalığı yemlerinde soya küspesi yerine yer fistığı küspesi kullanılması, CF ve $C$ gruplarına göre balık eti protein oranlarını düşürmüştür. 8 haftalık çalışmadan sonra, dorsal ve kaudal bölgelerdeki kırmızllık, sarılık ve Hue değerleri gruplar arasında farlılık göstermiştir. $\mathrm{C}$ ve $\mathrm{CF}$ gruplarının ölçüm yapılan tüm bölgelerde, renk parlaklığı açısından önemli bir farklılık görülmemiştir. Ölçüm yapılan bölgelerde $L^{*}, a^{*}, b^{*}$ değerlerinde oluşan farklılıkların, fileto kalınlığından ve filetonun renk maddesini muhafaza etmesinden kaynaklandığı düşünülmektedir. Sonuç olarak, alabalık diyetlerinde soya küspesi yerine\% 50 yer fistığı küspesi kullanımı, büyüme üzerinde herhangi bir olumsuz etki olmaksızın gökkuşağı alabalığının diyetlerinde kullanılabilir.

Anahtar kelimeler: Bitkisel protein, biyokimyasal kompozisyon, fileto rengi, Oncorhynchus mykiss, yer fistığ küspesi. 


\section{INTRODUCTION}

Global requisition for fish feed continues to rise in order to sustain the increasing aquaculture industry. Fish feed largely influences the success of aquaculture practice because it is the highest single cost of aquaculture (De Silva \& Turchini, 2009; Aydın \& Gumus, 2016; Pradhan et al., 2020). Thanks to its nutritional value and acceptability, fishmeal is considered a benchmark ingredient for fish feed and has historically been used as a major dietary protein source. However, the overrequisition and rising prices of fishmeal created interest in the use of alternate protein sources for fish diets. The need to replace fishmeal from feeds has been described as a major research priority (Tacon et al., 2011). In several feed formulations, terrestrial plant sources with high protein such as soybeans have been tried as an acceptable alternative to fishmeal (Deng et al., 2006; Collins et al., 2012). Soybean meal are a very quality source of protein (O'Keefe, 2003) and are currently introduced into the feed of carnivorous and omnivorous fish species to the degree of about 25-30\% and 50\%, respectively (Caruso, 2015). Requisition for soybean meal is constantly increasing with the addition of other livestock industries to their feed (Thoenes, 2014). Soybean meal is the most costly ingredient of fish feed, after fishmeal (Brown et al., 2008). However, there are anti-nutritional factors in soybean meal, such as trypsin inhibitor and phytate, which hinder the use of protein and essential minerals (Francis et al., 2001) and in some studies, high levels of soybean meal supplementation in fish feeds have been associated with intestinal problems in many fish species. (Hedrera et al., 2013; Wang et al., 2017). For that reasons, there is need for the replacement of soybean meal with other suitable terrestrial plant sources.

In feed formulations, there are several possible animal and plant ingredients that can be used. Proper detection of anti-nutritional factors can make it possible to use new plant ingredients in feed formulations. There are plenty of investigations carried out on using plant sources in both industrial by-products and animal nutrition (cottonseed meal: Yue \& Zhou, 2008; canola meal: Soares et al., 2001; Zhou \& Yue, 2010; sesame meal: Guo et al., 2011; Dernekbası \& Karayucel, 2017; peanut meal: Dernekbası \& Karayucel, 2017, Acar \&Turker, 2018).

The peanut (Arachis hypogaea L.) is the fourth largest oilseed crop in the world (Yildirim et al., 2014), with about 45.6 million tons of global production (Anonymous, 2020a). Peanut meal (PNM) is a by-product derived from the oil extraction of whole or separated peanut seeds and can usually be used as a protein source to replace soybean meal due to its high protein content (40.1-
$50.9 \%$ ) and lower cost than soybean meal (Goes et al., 2004; Batal et al., 2005; Acar \&Turker, 2018). Therefore, the aim of this study is to determine the potential effects of diets containing different ratios of peanut meal proteins $(50$ and $100 \%$ ) instead of soybean meal on the growth performance, feed conversion, biochemical composition and fillet color in rainbow trout by comparing both within the groups themselves and with the group using the commercial feed.

\section{MATERIAL AND METHOD}

Experimental Design: The study was performed at the indoor research and application center of the Sinop University Faculty of Fisheries. The rainbow trout (Oncorhynchus mykiss) were brought from a trading company (Kuzey Su Urunleri Inc.) in Samsun, Turkey. They were fed commercial feed (Black Sea Feed) for 15 days and adapted to the environment after the fish were taken to the testing and application center. Following adaptation, fish were weighed and randomly dispersed to twelve circular fiberglass tanks $(300 \mathrm{~L})$ with a density of 15 fish per tank. The experiment was scheduled as 4 groups (12 tanks) with three replications for 8 weeks and 15 fish were stocked in each tank $(108.70 \pm 0.09 \mathrm{~g})$, and each group was fed one of the four experimental diets. Water quality variables were measured daily; on average, the water temperature was $16.22 \pm 0.03^{\circ} \mathrm{C}$, dissolved oxygen was $8.32 \pm 0.01 \mathrm{mg} \mathrm{L}^{-1}$ and $\mathrm{pH}$ was $7.71 \pm 0.05$.

This study was conducted in compliance with the rules for animal experiments for scientific purposes and permission was given by the Sinop University, Animal Experiments Local Ethics Committee with permission No. 2020/02 on February 17th, 2020.

Diet Preparation. Peanut meal was obtained from a private corporation (Baspinar Toprak Mah. ve Nak. Ltd. Sti., Osmaniye, Turkey). The majority of the ingredients were supplied by a regional fish feed producer (SURSAN A.S., Sinop, Turkey). The experimental feeds containing peanut meal was prepared by chancing various extracted soybean meal ratios. While the $\mathrm{CF}$ group was fed with commercial feed, three experimental diets containing $0 \%$ (Control-C), 50\% ( $\left.\mathrm{PNM}_{50}\right)$ and $100 \%\left(\mathrm{PNM}_{100}\right)$ peanut flour were formulated for the other groups. All diets were prepared to be iso-nitrogenous (45\% protein), iso-lipidic (19\% lipid) iso-energetic (22 $\mathrm{kJ} \mathrm{g}^{-1}$; Table 1). Mixing, homogenization, moistening (35\% water addition), and pelleting (with a $4 \mathrm{~mm}$ mincer) were the methods of producing the feeds, respectively. Following the feed preparation process, the feed pellets were dried for $8 \mathrm{~h}$ at $50^{\circ} \mathrm{C}$, cut into pieces about $3 \mathrm{~mm}$ in length. All prepared feeds were stored at $-4{ }^{\circ} \mathrm{C}$ in plastic bags until used in the 
study. During the experiment, all fish groups were fed until satiation by hand twice a day (at 09:00 and 16:00) for 8 weeks. The fish $(n=5)$ were killed with anesthetic overdose at the beginning and at the end of the study (clove oil). All samples taken were stored in a deep freezer (WiseCryo/WUF-D500-80 ${ }^{\circ} \mathrm{C}$ ) until analysis.

Table 1. Formulation $(\mathrm{g} / \mathrm{kg})$ and proximate composition $(\%)$ of the experimental diets.

\begin{tabular}{|c|c|c|c|c|}
\hline & \multicolumn{4}{|c|}{ Experimental Diets } \\
\hline & Commercial feed $(\mathrm{CF})$ & $C$ (Control) & $P N M_{50}$ & $P N M_{100}$ \\
\hline \multicolumn{5}{|l|}{$\overline{\text { Nutrient }\left(g \mathrm{~kg}^{-1}\right)}$} \\
\hline Fish meal & - & 330 & 330 & 330 \\
\hline $\begin{array}{l}\text { Extracted soybean } \\
\text { meal }\end{array}$ & - & 255 & 127.5 & - \\
\hline Wheat flour & - & 153 & 140 & 150 \\
\hline Corn protein & - & 130 & 153 & 153 \\
\hline Peanut meal (PNM) & - & - & 127.5 & 255 \\
\hline Fish oil & - & 130 & 120 & 110 \\
\hline Vitamin premix $(*)$ & - & 1 & 1 & 1 \\
\hline Mineral premix $(*)$ & - & 1 & 1 & 1 \\
\hline \multicolumn{5}{|c|}{ Proximate Composition (\%) } \\
\hline Moisture & 10 & $3.33 \pm 0.04$ & $4.08 \pm 0.25$ & $3.54 \pm 0.08$ \\
\hline Protein & 46 & $44.87 \pm 0.58$ & $46.25 \pm 0.19$ & $45.01 \pm 0.24$ \\
\hline Lipid & 19 & $19.90 \pm 0.30$ & $19.73 \pm 0.77$ & $20.09 \pm 0.42$ \\
\hline Ash & 10 & $8.70 \pm 0.06$ & $9.02 \pm 0.12$ & $9.74 \pm 0.06$ \\
\hline$N F E^{I}$ & 1.5 & 23.20 & 20.92 & 21.62 \\
\hline Gross energy $\left(\mathrm{kJg}^{-1}\right)^{2}$ & 20.89 & 22.39 & 22.26 & 22.23 \\
\hline \multicolumn{5}{|c|}{$\begin{array}{l}\text { Vitamin-mineral premix (mg/kg premix): vitamin A, } 210000 \mathrm{IU} \text {; Vitamin } \mathrm{D}_{3}, 35000 \mathrm{IU} \text {; vitamin } \\
\mathrm{E}, 7000 \mathrm{mg} \text {; vitamin } \mathrm{K}_{3}, 322 \mathrm{mg} \text {; vitamin } \mathrm{B}_{1}, 588 \mathrm{mg} \text {; vitamin } \mathrm{B}_{2}, 252 \mathrm{mg} \text {; vitamin } \mathrm{B}_{6}, 294 \mathrm{mg} \text {; } \\
\text { vitamin } \mathrm{B}_{12}, 826 \mathrm{mcg} \text {; niacin, } 1400 \mathrm{mg} \text {; biotin, } 7583 \mathrm{mcg} ; 182 \mathrm{mg} \text { folic acid, pantothenic acid, } \\
1722 \mathrm{mg} \text {; inositol, } 17220 \mathrm{mg} \text {; vitamin C, } 933.31 \mathrm{mg} \text {; Ca, } 1414 \mathrm{mg} \text {. } \\
{ }^{1} \text { Nitrogen-Free Extract=100-(\%protein + \%lipid }+\% \text { ash } \% \text { moisture). } \\
{ }^{2} \text { Gross energy is calculated according to } 23.6 \mathrm{~kJ} \mathrm{~g}^{-1} \text { protein, } 39.5 \mathrm{~kJ} \mathrm{~g}^{-1} \text { lipid and } 17 \mathrm{~kJ} \mathrm{~g}^{-1} \mathrm{NFE} \text {. }\end{array}$} \\
\hline
\end{tabular}

Standard formula was used to assess growth, feed utilization and biometric parameters (Tablo 2), as previously described by Yigit et al. (2006) and Turchini et al. (2011).

Biochemical Composition: After the biometric measurements, all fish samples were cleaned from their viscera and the fish filets were used for analysis. Biochemical composition analyses were performed for both the diets and fish fillet. All biochemical analyses in fish fillets were made on a wet basis. All analyses [Dry matter (DM), crude protein (CP), crude lipid (CL), and crude ash (CA)] were performed according to the standard methods of the Association of Official Analytical Chemists (AOAC, 1995). DM was detected by drying the samples at $105{ }^{\circ} \mathrm{C}$ (for $20 \mathrm{~h}$ ) until a constant weight was achieved. CL was determined according to the procedure of the Soxhlet method. CP was determined as total nitrogen content by the Kjeldahl method. CA content was measured after samples were treated in a muffle furnace at $550{ }^{\circ} \mathrm{C}$ for $6 \mathrm{~h}$. All analyses were performed in triplicate.

Colour Analysis of Fish Fillet: Chroma Meter (CR-400, Konica Minolta Marunouchi, Tokyo, Japan), standardized for white plate as comparison before each calculation (standard values for white plate $\mathrm{L}^{*}=91.97$; $\mathrm{a}^{*}$ $=-1.4 ; \mathrm{b}^{*}=2.0$, Standard C2-22326), was used to determine the colour values ( $\mathrm{L}^{*}, \mathrm{a}^{*}$ and $\left.\mathrm{b}^{*}, \mathrm{CIE}, 1976\right)$ of fish fillet. The values of $\mathrm{L}^{*}, \mathrm{a}^{*}$ and $\mathrm{b}^{*}$ reflect lightness, redness, and yellowness. The Hue is a descriptor to whether the real colour is usually understood to be and the Chroma $\left(\mathrm{C}^{*}\right)$ is the colour's strength or saturation degree. The Hue and Chroma $\left(\mathrm{C}^{*}\right)$ angle are determined using the values of $\mathrm{a}^{*}$ and $\mathrm{b}^{*}$ (Kestin \& Warriss, 2001). Colour measurement of fillet was done from three locations: $1 \mathrm{st}$ location: between the behind of the operculum; 2nd location: front of the caudal fin.

$$
C *=\sqrt{a *^{2}+b^{* 2}} \quad \text { Hue }=\arctan \left(\frac{b^{*}}{a^{*}}\right)
$$

Statistical Analysis: All analysis results were presented as mean values \pm SE. Statistical analysis made with by using the IBM SPSS 21 statistical package program. The normality and equality of variance of the data were analyzed by Shapiro-Wilk normality and Levene's tests, respectively. The differences between the results were tested by one-way analysis of variance (ANOVA). The Tukey test was used for comparisons since the equality of the samples.

\section{RESULTS}

Growth Performance: In all the feeding procedures, the growth of rainbow trout increased considerably over the experimental period (Table 2). The final weight and weight gain were significantly higher in rainbow trout fed $\mathrm{PNM}_{50}(\mathrm{p}<0.05)$. The rainbow trout fed by $\mathrm{PNM}_{50}$ were higher in terms of specific growth rate (SGR) and feed conversion rate (FCR). While the lowest hepatosomatic (HSI) and viscerosomatic (VSI) index were in the CF and $\mathrm{C}$ groups, HSI and VSI were higher in rainbow trout groups fed $\mathrm{PNM}_{50}$ and $\mathrm{PNM}_{100}(\mathrm{p}<0.05)$, respectively.

Table 2. Growth performance, feed efficiency and biometric index of rainbow trout fed the 4 experimental diets for 8 weeks.

\begin{tabular}{|c|c|c|c|c|}
\hline & \multicolumn{4}{|c|}{ Diet groups } \\
\hline & $C F$ & $C$ & $P_{N M_{50}}$ & $P N M_{100}$ \\
\hline$I B W(g)$ & $108.97 \pm 0.49^{\mathrm{a}}$ & $108.77 \pm 0.24^{\mathrm{a}}$ & $108.47 \pm 0.19^{\mathrm{a}}$ & $108.63 \pm 0.24^{\mathrm{a}}$ \\
\hline$F B W(g)$ & $173.90 \pm 20.77^{\mathrm{c}}$ & $161.83 \pm 1.18^{\mathrm{a}}$ & $185.01 \pm 11.57^{\mathrm{d}}$ & $171.49 \pm 13.46^{\mathrm{b}}$ \\
\hline$W G(g)^{I}$ & $64.93 \pm 21.20^{\mathrm{c}}$ & $53.06 \pm 1.02^{\mathrm{a}}$ & $76.54 \pm 11.39^{\mathrm{d}}$ & $62.86 \pm 13.34^{\mathrm{b}}$ \\
\hline $\operatorname{SGR}(\%)^{2}$ & $0.85 \pm 0.24^{\mathrm{b}}$ & $0.75 \pm 0.01^{\mathrm{a}}$ & $1.00 \pm 0.12^{\mathrm{c}}$ & $0.85 \pm 0.15^{\mathrm{b}}$ \\
\hline$F C R^{3}$ & $2.64 \pm 0.90^{\mathrm{b}}$ & $2.94 \pm 0.49^{\mathrm{c}}$ & $1.79 \pm 0.11^{\mathrm{a}}$ & $2.62 \pm 0.48^{\mathrm{b}}$ \\
\hline HSI (\%) & $1.04 \pm 0.07^{\mathrm{a}}$ & $1.22 \pm 0.10^{\mathrm{b}}$ & $1.27 \pm 0.04^{\mathrm{c}}$ & $1.23 \pm 0.02^{\mathrm{b}}$ \\
\hline $\operatorname{VSI}(\%)^{5}$ & $11.21 \pm 0.35^{\mathrm{a}}$ & $11.11 \pm 0.54^{\mathrm{a}}$ & $12.55 \pm 0.33^{\mathrm{b}}$ & $12.73 \pm 0.08^{\mathrm{b}}$ \\
\hline $\begin{array}{l}\text { Data are repo } \\
\text { letter in a ro } \\
\text { weight. repli } \\
{ }^{1} \text { Weight gain } \\
{ }^{2} \text { Specific gro } \\
{ }^{3} \text { Feed conver } \\
{ }^{4} \text { Hepatosom } \\
5 \text { Viscerosom }\end{array}$ & $\begin{array}{l}\text { as mean } \pm \text { standa } \\
\text { e significantly d } \\
\\
\text {, g) }=\text { Final bod } \\
\text { ate }(\text { SGR })=[(\mathrm{ln} \\
\text { rate }(\mathrm{FCR})=\text { tota } \\
\text { dex }(\mathrm{HSI})=(\mathrm{liv} \\
\operatorname{ndex}(\mathrm{VSI})=(\mathrm{vis}\end{array}$ & $\begin{array}{l}\text { rors of three rep } \\
\text { nt (p>0.05). IB } \\
\text { ght - initial boo } \\
\text { wet weight - } \\
\text { d intake/weight } \\
\text { eight / body we } \\
\text { weight/body w }\end{array}$ & $\begin{array}{l}\text { Initial body wei } \\
\text { eight. } \\
\text { tial wet weight)/ } \\
\text { n. } \\
x 100 \text {. } \\
\text { t) } x 100 \text {. }\end{array}$ & $\begin{array}{l}\text { fferent superscri } \\
\text { FBW: Final bo } \\
\text { x } 100 \text {. }\end{array}$ \\
\hline
\end{tabular}

Biochemical Composition: The biochemical composition of fillet of rainbow trout was influenced by the incorporation of PNM replacement of soybean meal ( $\mathrm{p}<0.05$; Table 3$)$. While the significantly lower protein content of rainbow trout fillet was in the $\mathrm{PNM}_{50}$ and $\mathrm{PNM}_{100}$ groups $(\mathrm{p}<0.05)$, the $\mathrm{CF}$ and $\mathrm{C}$ groups were similar protein content. Although the lipid content of rainbow trout 
fillet was the highest in $\mathrm{PNM}_{50}$ group ( $\left.\mathrm{p}<0.05\right)$, there was no statistically significant difference between with $\mathrm{C}$ group. In terms of lipid content, there was also no statistical difference between the $\mathrm{C}, \mathrm{CF}$ and $\mathrm{PNM}_{100}$ groups. $(p>0.05)$. The ash content of rainbow trout fillet was significantly higher in the $\mathrm{PNM}_{50}$ group $(\mathrm{p}<0.05)$.

Table 3. Biochemical composition of fillet of rainbow trout fed the four experimental diets for 8 weeks (\% wet weight).

\begin{tabular}{lcccc}
\hline & Moisture (\%) & Protein (\%) & Lipid (\%) & Ash $(\%)$ \\
\cline { 2 - 5 } $\boldsymbol{C} \boldsymbol{C}$ & $25.92 \pm 0.07^{\mathrm{ab}}$ & $24.51 \pm 0.60^{\mathrm{a}}$ & $2.82 \pm 0.24^{\mathrm{b}}$ & $2.22 \pm 0.10^{\mathrm{b}}$ \\
$\boldsymbol{P}$ & $26.21 \pm 0.18^{\mathrm{ab}}$ & $24.26 \pm 0.29^{\mathrm{a}}$ & $3.35 \pm 0.15^{\mathrm{ab}}$ & $2.34 \pm 0.14^{\mathrm{ab}}$ \\
$\boldsymbol{P N M}_{\boldsymbol{5} 0}$ & $26.43 \pm 0.19^{\mathrm{a}}$ & $21.16 \pm 0.31^{\mathrm{b}}$ & $4.01 \pm 0.11^{\mathrm{a}}$ & $2.86 \pm 0.07^{\mathrm{a}}$ \\
$\boldsymbol{P N M}_{\mathbf{1 0 0}}$ & $25.57 \pm 0.13^{\mathrm{b}}$ & $20.56 \pm 0.24^{\mathrm{b}}$ & $2.88 \pm 0.01^{\mathrm{b}}$ & $2.39 \pm 0.13^{\mathrm{ab}}$ \\
\hline Data are mean \pm SE. Means with different superscript letter in a column are significantly different
\end{tabular}
( $>>0.05)$.

Colour Analysis of Fish Fillet: Color parameters $\left(L^{*}, a^{*}, b^{*}, C^{*}\right.$ and Hue) for fillet of rainbow trout fed with experimental diets are shown in Table 4. Average lightness $\left(L^{*}\right)$ values of the rainbow trout fillets was a significant difference between the $\mathrm{PNM}_{50}$ and the $\mathrm{CF}$ and $\mathrm{C}$ diet groups $(\mathrm{P}<0.05)$. The higher $\mathrm{L}^{*}$ values in the caudal part of the rainbow trout fillet in the $\mathrm{C}, \mathrm{PNM}_{50}$ and $\mathrm{PNM}_{100}$ groups were higher in the dorsal part of the $\mathrm{CF}$ group. The $\mathrm{a}^{*}$ and $\mathrm{b}^{*}$ of rainbow trout fillet firstly increased until $\mathrm{PNM}_{50}$ group and then decreased $\mathrm{PNM}_{100}$ group. Contrary to other color parameters, the average Hue value is high in group $\mathrm{CF}$ and the statistical difference among values is significant $(\mathrm{p}<0.05)$.

Table 4. The $\mathrm{L}^{*}, \mathrm{a}^{*}, \mathrm{~b}^{*}, \mathrm{C}^{*}$ and Hue values of fillet of rainbow trout fed the experimental diets for 8 weeks.

\begin{tabular}{|c|c|c|c|}
\hline & \multicolumn{3}{|c|}{ Fish Fillet } \\
\hline & Dorsal & Caudal & Average \\
\hline \multicolumn{4}{|l|}{$\boldsymbol{C F}$} \\
\hline$L^{*}$ & $47.34 \pm 0.78^{\text {ay }}$ & $47.25 \pm 0.86^{\mathrm{ax}}$ & $47.29 \pm 0.53^{y}$ \\
\hline$a^{*}$ & $1.63 \pm 0.11^{\text {at }}$ & $4.37 \pm 0.89^{\mathrm{bt}}$ & $3.00 \pm 0.64^{\mathrm{xy}}$ \\
\hline$b^{*}$ & $4.36 \pm 0.75^{\text {at }}$ & $10.46 \pm 0.93^{\mathrm{bx}}$ & $7.41 \pm 1.06^{\mathrm{tx}}$ \\
\hline$C^{*}$ & $4.79 \pm 0.73^{\text {at }}$ & $11.47 \pm 1.01^{\mathrm{bx}}$ & $8.13 \pm 1.16^{t}$ \\
\hline Hue & $1.21 \pm 0.02^{\mathrm{bz}}$ & $1.18 \pm 0.07^{\text {ay }}$ & $1.20 \pm 0.07^{\mathrm{yz}}$ \\
\hline \multicolumn{4}{|l|}{$C$} \\
\hline$L^{*}$ & $46.30 \pm 1.02^{\mathrm{ax}}$ & $46.64 \pm 1.06^{\mathrm{at}}$ & $46.47 \pm 0.75^{\mathrm{t}}$ \\
\hline$a^{*}$ & $3.38 \pm 0.25^{\mathrm{az}}$ & $5.44 \pm 0.72^{\text {by }}$ & $4.41 \pm 0.45^{2}$ \\
\hline$b^{*}$ & $5.02 \pm 1.77^{\mathrm{ax}}$ & $10.01 \pm 0.55^{\text {by }}$ & $7.51 \pm 0.85^{x}$ \\
\hline$C^{*}$ & $6.15 \pm 1.54^{\mathrm{ax}}$ & $11.44 \pm 0.76^{b x}$ & $8.79 \pm 0.90^{\mathrm{x}}$ \\
\hline Hue & $0.99 \pm 0.12^{\mathrm{ax}}$ & $1.08 \pm 0.04^{\mathrm{bt}}$ & $1.04 \pm 0.05^{\mathrm{x}}$ \\
\hline \multicolumn{4}{|c|}{$P N M_{50}$} \\
\hline$L^{*}$ & $48.55 \pm 0.66^{\mathrm{az}}$ & $51.00 \pm 0.74^{\text {by }}$ & $49.77 \pm 0.58^{z}$ \\
\hline$a^{*}$ & $2.96 \pm 0.67^{\text {ay }}$ & $5.93 \pm 0.60^{\mathrm{bz}}$ & $4.44 \pm 0.53^{2}$ \\
\hline$b^{*}$ & $6.49 \pm 1.47^{\text {ay }}$ & $11.18 \pm 1.26^{\mathrm{bz}}$ & $8.83 \pm 0.86^{\mathrm{z}}$ \\
\hline$C^{*}$ & $7.17 \pm 1.53^{\mathrm{az}}$ & $12.70 \pm 1.30^{\text {by }}$ & $9.94 \pm 0.94^{z}$ \\
\hline Hue & $1.17 \pm 0.06^{\text {by }}$ & $1.07 \pm 0.05^{\text {at }}$ & $1.12 \pm 0.04^{x y}$ \\
\hline \multicolumn{4}{|c|}{$P N M_{100}$} \\
\hline$L^{*}$ & $45.92 \pm 0.57^{\text {7t }}$ & $47.28 \pm 0.80^{\mathrm{bx}}$ & $46.60 \pm 0.62^{\mathrm{xx}}$ \\
\hline$a^{*}$ & $2.10 \pm 0.49^{\mathrm{ax}}$ & $4.83 \pm 0.78^{b x}$ & $3.46 \pm 0.64^{y}$ \\
\hline$b^{*}$ & $6.45 \pm 1.43^{\text {ay }}$ & $9.65 \pm 0.93^{\mathrm{bt}}$ & $8.08 \pm 0.62^{y}$ \\
\hline$C^{*}$ & $6.92 \pm 1.47^{\text {ay }}$ & $10.89 \pm 1.02^{\mathrm{bt}}$ & $8.91 \pm 0.75^{y}$ \\
\hline Hue & $0.74 \pm 0.04^{\text {at }}$ & $1.11 \pm 0.06^{\mathrm{bx}}$ & $0.93 \pm 0.24^{t}$ \\
\hline
\end{tabular}

\section{DISCUSSION}

A much-awaited breakthrough in the aquaculture industry is the successful replacement of fish meal with plant substitutes in fish feed. Many research has been carried out for several years on the use of different plant- based protein sources instead of fish meal and soybean meal (also plant based protein source) as a source of protein in fish feeds (Bilguven \& Baris, 2011; Da et al., 2012; Yuangsoi et al., 2014; Emadi et al., 2014; Dernekbas1 \& Karayucel, 2017). In addition to these studies, this study aims to reveal the effects of adding different amounts of peanut meal instead of soybean meal in rainbow trout diet on growth performance, biochemical composition and fillet color of rainbow trout. The results of the present study indicated that $\mathrm{PNM}_{50}$ could be included in the diet of rainbow trout up to a level of $\% 50$, which could replace soybean meal, without depressing growth performance and feed utilization. Moreover, according to the control group, the addition of $100 \%$ peanut meal $\left(\mathrm{PNM}_{100}\right)$ instead of soybean meal in rainbow trout diets showed a good growth performance, but when the feed conversion ratios were compared, the $\mathrm{PNM}_{50}$ group came to the fore. In different studies reported that the use of plant-based protein sources at different rates in fish feed does not have a negative effect on the growth and feed conversion rates of the studied species (Clarias gariepinus: Fagbenro et al., 2010; Oreochromis niloticus: Da Silva et al., 2017; Oncorhynchus mykiss: Dernekbaşı et al., 2017; Dernekbaşı \& Karayücel, 2017; Acipenser gueldenstaedtti: Emre et al., 2018).

When the biometric index values were examined, VSI values of rainbow trout fed with feeds containing peanut meal ( $\mathrm{PNM}_{50}$ and $\mathrm{PNM}_{100}$ ) were different from $\mathrm{CF}$ and $\mathrm{C}$ groups. In studies using alternative vegetable protein sources instead of soybean meal in feeds, it was stated that the VSI value increased (Yigit et al., 2013; Dernekbas1 \& Karayucel, 2017; Pradhan et al., 2020). It has been reported that the VSI value can be between $13 \%$ and $24 \%$ and this value can be associated with fish size and successful feed use (Bugeon et al. 2010; Dernekbası \& Karayucel, 2017). In the present study, HSI values of $\mathrm{PNM}_{50}$ and $\mathrm{PNM}_{100}$ groups containing peanut meal were found to be higher when compared with the $\mathrm{CF}$ and $\mathrm{C}$ groups. Several studies have reported an increase in HSI values for fish species fed diets containing various plant-based protein sources (canola, wheat gluten, sweet white lupine, and cashew nuts) instead of soybean meal (Sparus aurata: SitjàBobadilla et al., 2005; Gadus morhua: Hansen et al., 2007; Cyprinus carpio: Yigit et al., 2013; Oreochromis mossambicus: Pradhan et al., 2020). In addition, Dernekbası (2012) reported that the HSI value should be between $1 \%$ and $2 \%$ for bony fish (Osteichthyes). The results of HSI in this study were in line with the literature previous.

Fish body composition was not significantly different among groups, except for protein. In the present study, the level of fillet protein decreased with increasing dietary levels of PNM. Acar \& Turker (2018) reported that 
there was no harmful impact on the biochemical composition of fish fillet the use of PNM instead of soybean meal in rainbow trout diets. The use of PNM instead of soybean meal in Nile tilapia (Oreochromis niloticus) feeds have been reported to have lowered the protein ratio of fish meat relative to the control group (De Silva et al., 2017). In the same study, the lipid ratios for tilapia fillet fed with $\mathrm{PNM}_{50}$ added feed were found to be the highest, while the lipid ratios for the $\mathrm{PNM}_{100}$ added feed group were similar to those for the control group. Conclusions of this research are consistent with our current study. Various studies were documented that plant origin raw materials added instead of soya meal in fish feeds have an effect on protein and lipid ratios in fish fillets (Fagbenro et al., 2010; Jimoh et al., 2013; Dernekbas1 et al., 2017; Pradhan et al., 2020). The differences between the previous studies and the present research are believed to be due to the digestibility of the raw materials of plant origin added instead of the soybean meal.

In fish, color is far more than a superficial effect; customers equate nutritious and high-quality items with natural coloration. Muscle pigmentation in farmed salmonids, for example, is considered the most significant quality parameter after freshness. The variability of the intra-fillet color was another important aspect. There was no interaction between sampling location and diet, indicating that all fillets were presented with the same color difference in the different locations analyzed. It has been reported in studies that the measurement location has a very important effect on fish fillets (De Francesco et al., 2004). As regards fillet color, some differences were observed at each of the two points of measure. The qualities of redness, yellowness and hue were distinct between the diets in the dorsal and caudal locations. At all the measured regions in the $\mathrm{C}$ and $\mathrm{CF}$ groups did not result in any significant difference for chroma. It is assumed that the differences between the measured regions in $\mathrm{L}^{*}, \mathrm{a}^{*}, \mathrm{~b}$ $*$ are due to the fillet thickness and the preservation of the fillet coloring matter. Color changes in fish fillets, which are usually caused by feed ingredients, can have a negative effect if they do not meet the expectations of customers. Considering the average values in fish fillet color analysis, lightness, redness, yellowness and chroma values came to the fore in the $\mathrm{PNM}_{50}$ group. However, it cannot be clearly stated that the addition of PNM to feeds instead of soybean meal affects the color of fish fillets. Because the feeds used in the experiment were contained raw materials such as corn protein that affect the color of fish fillets. There is no literature on the effect of peanut meal added to fish feeds on fish fillet color. Previous studies consist of the effects of fish fed with feed containing high carotene containing vegetable raw materials on the color of the fillet (Skonberg et al., 1998; De Francesco et al., 2004; Herath et al., 2016; Yanar et al., 2016; Shekarabi et al., 2020).

\section{CONCLUSION}

The use of peanut meal instead of soybean meal in the rainbow trout diet did not affect the growth negatively. Also, rainbow trout, which was fed with $50 \%$ PNM added instead of soybean meal, grew relatively well compared to the $\mathrm{CF}$ and $\mathrm{C}$ groups. Further study to determine the impact on biochemical composition of fish fillet by detailing the use of peanut meal in fish feed instead of soybean meal should be carried out. As a result, it is thought that by using a peanut meal, a local product, in rainbow trout feeds instead of soybean meal, it can produce a lower-cost feed.

\section{REFERENCES}

Acar, U. \& Turker, A. (2018). The effects of using peanut meal in rainbow trout (Oncorhynchus mykiss) diets on the growth performance and some blood parameters. Aquaculture Studies, 18(2), 5-13.

Anonymous.

(2020a).

https://www.nationalpeanutboard.org/peanutinfo/peanut-country-usa.htm\#: :text=As\%20of $\% 202019 \% 2 \mathrm{C} \% 20$ the $\% 20$ United,\%2C\%20Burm a\%2C\%20Argentina\%20and\%20Senegal. (Date of Access 17.12.2020).

Anonymous. (2020b). https://www.atlasbig.com/enus/countries-peanut-production (Date of Access 17.12.2020).

AOAC. (1995). Official Methods of Analysis of AOAC International. AOAC Int., Gaithersburg MD.

Aydin, B. \& Gumus, E. (2016). Balık yemlerinde alternatif hammadde kaynağı: Kurutulmuş damıtma kalıntıları ve çözünür maddeleri (DDGS). Journal of Anatolian Environmental \& Animal Sciences, 1(3), 87-91.

Batal, A., Dale, N. \& Cafe, M. (2005). Nutrient composition of peanut meal. Journal of Applied Poultry Research, 14, 254-257.

Bilguven, M. \& Baris, M. (2011). Effects of the feeds containing different plant protein sources on growth performance and body composition of rainbow trout (Oncorhynchus mykiss, W.). Turkish Journal of Fisheries \& Aquatic Sciences, 11(3), 345-350.

Brown, P.B., Kaushik, S.J. \& Peres, H. (2008). Protein feedstuffs originating from soybeans. Alternative protein sources in aquaculture diets (205-223pp). New York: The Haworth press, Taylor and Francis group.

Bugeon, J., Lefevre, F., Cardinal, M., Uyanı, A., Davenel, A. \& Haffray, P. (2010). Flesh quality in large rainbow trout with high or low fillet yield. Journal of Muscle Foods, 21(4), 702-721. 
Caruso, G. (2015). Use of plant products as candidate fish meal substitutes: An emerging issue in aquaculture productions. Fisheries and Aquaculture Journal, 6(3), 1.

Collins, S.A., Desai, A.R., Mansfield, G.S., Hill, J.E., van Kessel, A.G. \& Drew, M.D. (2012). The effect of increasing inclusion rates of soybean, pea and ca nola meals and their protein concentrates on the growth of rainbow trout: concepts in diet formulation and experimental design for ingredient evaluation. Aquaculture. 344, 90-99 DOI: 10.1016/j.aquaculture.2012.02.018

Da, C.T., Lundh, T. \& Lindberg, J.E. (2012). Evaluation of local feed resources as alternatives to fish meal in terms of growth performance, feed utilisation and biological indices of striped catfish (Pangasianodon hypophthalmus) fingerlings. Aquaculture, 364, 150-156.

Da Silva, R.L., Damasceno, F.M., Rocha, M.K.H.R., Sartori, M.M.P., Barros, M.M. \& Pezzato, L.E. (2017). Replacement of soybean meal by peanut meal in diets for juvenile Nile tilapia, Oreochromis niloticus. Latin American Journal of Aquatic Research, 45(5), 1044-1053.

Deng, J., Mai, K., Ai, Q., Zhang, W., Wang, Y., Xu, W. \& Liufu, Z. (2006). Effects of replacing fish meal with soy protein concentrate on feed intake and growth of juvenile japanese flounder, (Paralichthys olivaceus). Aquaculture, 258, 503513.

Dernekbası, S. (2012). Digestibility and liver fatty acid composition of rainbow trout (Oncorhynchus mykiss) fed by graded levels of canola oil. Turkish Journal of Fisheries \& Aquatic Sciences, 12, 105113.

Dernekbası, S. \& Karayucel, I. (2017). Partial replacement of soybean meal by peanut and sesame seed meals in practical diets for rainbow trout, Oncorhynchus mykiss. J Aquac Mar Biol, 6(1), 00146.

Dernekbası, S., Karayucel, İ. \& Parlak Akyuz, A. (2017). Evaluation of sesame (Sesamum indicum) seed meal as a replacer for soybean meal in the diets of rainbow trout (Oncorhynchus mykiss Walbaum, 1792). Ege Journal of Fisheries and Aquatic Sciences, 34(1), 31-39. DOI: 10.12714/egejfas.2017.34.1.05

De Francesco, M., Parisi, G., Médale, F., Lupi, P., Kaushik, S.J. \& Poli, B.M. (2004). Effect of long-term feeding with a plant protein mixture based diet on growth and body/fillet quality traits of large rainbow trout (Oncorhynchus mykiss). Aquaculture, 236(1-4), 413-429.

De Silva, S.S. \& Turchini, G.M. (2009). Use of wild fish and other aquatic organisms as feed in aquacultur-A review of practices and implications in the Asia-Pacific. In M. R. Hasan, \& M. Halwart (Eds.), Fish as feed inputs for aquaculture: Practices, sustainability and implications. FAO Fisheries and Aquaculture Technical Paper. No. 518. Rome, FAO. 63-127pp.
Emadi, H., Mokhayer, B. \& Faal, M. (2014). Alternative role of sesame seed replacing fish meal in the diet of rainbow trout (Oncorhynchus mykiss) fingerlings. Iranian Journal of Fisheries Sciences, 13(3), 608-620.

Emre, N., Guroy, D., Yalim, F.B., Emre, Y., Guroy, B., Mantoglu, S. \& Karadal, O. (2018). Growth Performance, Body Composition, Haematological and Serum Parameters to Fish Meal Replacement by Soybean Meal and Cottonseed Meal in Russian Sturgeon (Acipenser gueldenstaedtii). LimnoFish. 4(3), 169-176. DOI: 10.17216/limnofish.460773

Fagbenro, O.A., Adeparusi, E.O. \& Jimoh, W.A. (2010). Nutritional evaluation of sunflower and sesame seed meal in Clarias gariepinus: An assessment by growth performance and nutrient utilization. African Journal of Agricultural Research, 5(22), 3096-3101.

Francis, G., Makkar, H.P.S. \& Becker, K. (2001). Antinutritional factors present in plant-derived alternate fish feed ingredients and their effects in fish. Aquaculture, 199(3-4), 197-227.

Goes, R.H.T.B., Mancio, A.B., Valadares Filho, S.C. \& Lana, R.P. (2004). Degradação ruminal da matéria seca e proteína bruta, de alimentos concentrados utilizados como suplementos para novilhos. Ciência e Agrotecnologia, 28(1), 167173.

Guo, Y.X., Dong, X.H., Tan, B.P., Chi, S.Y., Yang, Q.H., Chen, G. \& Zhang, L. (2011). Partial replacement of soybean meal by sesame meal in diets of juvenile Nile tilapia, Oreochromis niloticus L. Aquaculture Research, 42, 12981307.

Hansen, A.C., Rosenlund, G., Karlsen, Ø., Koppe, W. \& Hemre, G.I. (2007). Total replacement of fish meal with plant proteins in diets for Atlantic cod (Gadus morhua L.) I-Effects on growth and protein retention. Aquaculture, 272, 599-611.

Hedrera, M.I., Galdames, J.A., Jimenez-Reyes, M.F., Reyes, A.E., Avendaño-Herrera, R., Romero, J. \& Feijóo, C.G. (2013). Soybean meal induces intestinal inflammation in zebrafish larvae. PLoS ONE, 8(7), e69983. DOI: 10.1371/journ al.pone.0069983

Herath, S.S., Haga, Y. \& Satoh, S. (2016). Effects of long-term feeding of corn co-product-based diets on growth, fillet color, and fatty acid and amino acid composition of Nile tilapia, Oreochromis niloticus. Aquaculture, 464, 205-212.

Jimoh, W.A., Aderolu, A.Z., Ayeloja, A.A. \& Shodamola, M.O. (2013). Replacement value of soybean meal with luffa cylindrical in diet of Clarias gariepinus fingerlings. International Journal of Applied Agriculture \& Apiculture Research, 9(1-2), 98-105.

Kestin, S.C. \& Warriss, P.D. (2001). Farmed fish quality. Oxford, UK: Blackwell Science Ltd, Fishing News Books. 2001. ISBN 0-85238-260-X. 
O'Keefe, T. (2003). Plant protein ingredients for aquaculture feeds: Use considerations \& quality standards. Seeds, 5, 04-597.

Pradhan, C., Divi, B.G., Dileep, N., Peter, N. \& Sankar, T.V. (2020). Replacement of soya bean meal with cashew nut meal as an alternative protein source in the diet of tilapia, Oreochromis mossambicus. Aquaculture Research, 51(4), 1660-1672.

Sitjà-Bobadilla, A., Peña-Llopis, S., Gómez-Requeni, P., Médale, F., Kaushik, S. \& Pérez-Sánchez, J. (2005). Effect of fish meal replacement by plant protein sources on non-specific defence mechanisms and oxidative stress in gilthead sea bream (Sparus aurata). Aquaculture, 249, 387400.

Shekarabi, S.P.H., Omidi, A.H., Dawood, M.A., Adel, M., Avazeh, A. \& Heidari, F. (2020). Effect of black mulberry (Morus nigra) powder on growth performance, biochemical parameters, blood carotenoid concentration, and fillet color of rainbow trout. Annals of Animal Science, 20(1), 125-136.

Skonberg, D.I., Hardy, R.W., Barrows, F.T. \& Dong, F.M. (1998). Color and flavor analyses of fillets from farm-raised rainbow trout (Oncorhynchus mykiss) fed low-phosphorus feeds containing corn or wheat gluten. Aquaculture, 166(3-4), 269-277.

Soares, C.M., Hayashi, C., Faria, A.C.E.A. \& Furuya, W.M. (2001). Substituição da proteína do farelo de soja pela proteína do farelo de canola em dietas para a tilápia do Nilo (Oreochromis niloticus) na fase de crescimento. Revista Brasileira de Zootecnia, 30(4), 1172-1177.

Tacon, A.G.J., Hasan, M.R. \& Metian, M. (2011). Demand and supply of feed ingredients for farmed fish and crustaceans: trends and prospects. FAO Fisheries and Aquaculture Technical Paper. No. 564. Rome: FAO.

Thoenes, P. (2014). Background paper for the Competitive Commercial Agriculture in Sub-Saharan Africa (CCAA) Study. Soya bean International Commodity Profile. Markets and Trade Division Food and Agriculture Organization of the United Nations.

Turchini, G.M., Francis, D.S., Senadheera, S.P.S.D., Thanuthong, T. \& De Silva, S.S. (2011). Fish oil replacement with different vegetable oils in Murray cod: Evidence of an "omega-3 sparing effect" by other dietary fatty acids. Aquaculture, 315(3-4), 250-259. DOI: 10.1016/j.aquac ulture.2011.02.016

Wang, YR., Wang, L., Zhang, C.X. \& Song, K. (2017). Effects of substituting fishmeal with soybean meal on growth performance and intestinal morphology in orange-spotted grouper (Epinephelus coioides). Aquaculture Reports, 5, 52-57. DOI: 10.1016/j.aqrep.2016.12.005

Yanar, M., Büyükçapar, H.M. \& Yanar, Y. (2016). Effects of hot and sweet red peppers (Capsicum annuиm) as feed supplements on pigmentation, sensory properties and weight gain of rainbow trout (Onchorhynchus mykiss). Annals of Animal Science, 16(3), 825-834.

Yildirim, O., Acar, U., Turker, A., Sunar, M.C. \& Kesbic, O.S. (2014). Effects of replacing fish meal with peanut meal (Arachis hypogaea) on growth, feed utilization and body composition of Mozambique tilapia fries (Oreochromis mossambicus). Pakistan Journal of Zoology, 46(2), 497-502.

Yigit, M., Erdem, M., Koshio, S., Ergun, S., Turker, A. \& Harmantepe, F.B. (2006). Substituting fish meal with poultry by product meal in diets for Black Sea Turbot Psetta maeotica. Aquaculture Nutrition, 12, 340-347. DOI: 10.1111/j.13652095.2006.00409.x

Yigit, N.Ö., Dulluc, A., Koca, S.B. \& Didinen, B.I. (2013). Aynalı sazan (Cyprinus carpio, L. 1758) yemlerinde soya küspesi yerine kanola küspesi kullanımının büyüme ve vücut kompozisyonu üzerine etkisi. Tarım Bilimleri Dergisi /Journal Of Agricultural Sciences, 19, 140-147

Yuangsoi, B., Klahan, R. \& Charoenwattanasak, S. (2014). Partial replacement of protein in soybean meal by moringa seed cake (Moringa oleifera) in bocourti's catfish (Pangasius bocourti). Songklanakarin Journal of Science \& Technology, 36(2), 125-135.

Yue, Y.R. \& Zhou, Q.C. (2008). Effect of replacing soybean meal with cottonseed meal on growth, feed utilization, and hematological indexes for juvenile hybrid tilapia, Oreochromis niloticus $\times O$. aureus. Aquaculture, 284, 185-189.

Zhou, Q.C. \& Yue, Y.R. (2010). Effect of replacing soybean meal with canola meal on growth, feed utilization and hematological indices of juvenile hybrid tilapia, Oreochromis niloticus $\times$ Oreochromis aureus. Aquaculture Research, 41(7), 982-990. 